\title{
BUB1 Gene
}

National Cancer Institute

\section{Source}

National Cancer Institute. BUB1 Gene. NCI Thesaurus. Code C21494.

This gene is a modulator of the mitotic spindle cell cycle checkpoint. 